\title{
EUCALYPTUS INICIAL GROWTH ON HUMIC CAMBISOL WITH APPLICATION OF LIMESTONE, GYPSUM, AND LIME MUD
}

\author{
Priscylla Pfleger ${ }^{1 *}$, Paulo Cezar Cassol $^{1}$, Marcia Aparecida Simonete ${ }^{2}$ \\ ${ }^{1}$ Universidade do Estado de Santa Catarina, Programa de Pós Graduação em Ciência do Solo, Departamento de Solos e Recursos Naturais, \\ Lages, Santa Catarina, Brasil - cyllapfleger@hotmail.com*, paulo.cassol@udesc.br \\ ${ }^{2}$ Blumeterra, Otacílio Costa, Santa Catarina, Brasil - marciasimonete@gmail.com \\ Received for publication: 28/03/2019 - Accepted for publication: 05/06/2020
}

\begin{abstract}
Resumo
Crescimento inicial de eucalipto em Cambissolo Húmico com aplicação de calcário, gesso e lama de cal. A elevada demanda por produtos florestais no Brasil projeta um aumento de 2 milhões de hectares de reflorestamentos nos próximos 10 anos, com destaque para espécies de eucalipto. Entretanto, os plantios no país geralmente ocorrem em solos ácidos que necessitam de correção para se atingir alta produtividade. Além do calcário, o resíduo "lama de cal" da indústria de celulose e o gesso agrícola também podem ser utilizados como corretivos, mas há dúvidas quanto às doses e formas de aplicação com melhores resultados. Assim, foram avaliados atributos químicos do solo, teores foliares de nutrientes e o crescimento inicial de um plantio de Eucalyptus dunnii Maiden em resposta à aplicação de calcário, lama de cal e gesso agrícola, em diferentes doses e formas de aplicação, em um Cambissolo Húmico do Planalto Catarinense. O experimento foi conduzido com nove tratamentos e quatro repetições, onde os parâmetros avaliados foram determinados no período até 24 meses após o plantio. Em geral, tanto o calcário, quanto a lama de cal e o gesso agrícola, nas diferentes doses e formas de aplicação, afetaram os atributos químicos do solo, porém não afetaram os teores foliares dos nutrientes aos 12 meses, a altura e diâmetro à altura do peito (DAP) das árvores e volume de madeira aos 24 meses. O gesso não corrige a acidez do solo, mas a lama de cal proporciona resultados semelhantes ao calcário indicando que pode substituir esse corretivo sem prejuízos no estado nutricional e no desenvolvimento inicial de Eucalyptus dunnii.

Palavras-chave: Resíduo alcalino; Eucalyptus dunnii; calagem; volume de madeira.
\end{abstract}

\begin{abstract}
The high demand for forest products in Brazil estimates a 2 million hectares increase in reforestation areas over the next 10 years, highlighting Eucalyptus species. However, these crops usually occur in acid soils that need correction to achieve high productivity. Besides limestone, lime mud, a residue from the cellulose industry, and gypsum can also be used as correctives, but there are doubts about doses and ways of application with the best results. Thus, were evaluated the soil chemical attributes, foliar nutrient content, and initial growth of a Eucalyptus dunnii Maiden crop in response to the application of limestone, lime mud, and gypsum in different doses and ways of applications, on a Humic Cambisol from Santa Catarina Plateau. The experiment was carried out with nine treatments in four replicates, where the evaluated parameters were determined up to 24 months after planting. In general, both limestone, lime mud, and gypsum, in different doses and ways of application, affected the chemical attributes of the soil but did not affect the foliar nutrient content at 12 months, height, and diameter at breast high (DBH) from trees and timber volume at 24 months. Gypsum do not correct soil acidity but lime mud provides similar results to limestone indicating that can substitute this corrective without damage to nutritional status and initial development of Eucalyptus dunnii.

Keywords: Alkali residue; Eucalyptus dunnii; liming; timber volume.
\end{abstract}

\section{INTRODUCTION}

Brazil has a wide area covered by natural and planted forests. From the total area with planted forests, $72 \%$ are represented by eucalyptus plantations, whose production stands out worldwide for the high yield, and competitiveness regarding production costs (GUIMARÃES et al., 2015). Most of the eucalyptus plantations in Santa Catarina occur in highlands, such as the Santa Catarina Plateau, where the soil has low pH, high content of exchangeable $\mathrm{Al}$, and low contents of $\mathrm{Ca}$ and $\mathrm{Mg}$, requiring a correction of soil acidity to provide better conditions for plant growth (ALMEIDA et al., 1999; SIMONETE et al., 2013).

The Eucalyptus, due to its high adaptability to climatic conditions and different soils, is considered as tolerant to acidity and low soil fertility, and as non-responsive to any soil correction (CQFS, 2016). However, several studies indicate an increase in productivity when using fertilizers and soil acidity correctives (CASTRO FARIA et al., 2015; VIEIRA; WEBER, 2017; RODRIGUES et al., 2016; MAEDA et al., 2015; GUIMARÃES et al., 2015). Because of the high costs of applying these products, even at the beginning of the production process, and the scarcity of resources, the administration of doses below the necessary may occur, resulting in low crop yields. Thus, studies on doses and ways of application of gypsum as soil conditioning, limestone and other potential 
correctives (such as lime mud) are necessary in order to improve the current recommendations in view of the expansion of eucalyptus plantations in the southern of Brazil (ALMEIDA et al., 1999; ROCHA et al., 2008; GUIMARÃES et al., 2015).

In the pulp and paper industry, many residues are generated, such as lime mud, a product of causticizing for recovery of cooking liquor. This residue is mainly made up of $\mathrm{Ca}$ carbonate and has a great potential to increase the soil pH (SIMONETE et al., 2013). However, for the long term, more detailed studies of its effects on soil are necessary, since the presence of $\mathrm{Na}$ in its composition may lead to the dispersion of soil colloids, because of its effect on the expansion of the diffuse double layer, by moving them in the profile so that they can obstruct pores interfering in the soil physical properties and affecting the growth of cultures (HOMEM et al., 2012).

Research carried out with alkaline residues from the pulp and paper industry shows an increase in eucalyptus productivity, given changes in soil properties (CASTRO FARIA et al., 2015). Several authors reported an increase in biomass (VIEIRA; WEBER, 2017) and timber volume of eucalyptus (RODRIGUES et al., 2016; MAEDA et al., 2015; GUIMARÃES et al., 2015) after the addition of limestone or industrial residues.

Considering the information presented above, this study proposes to evaluate the $\mathrm{pH}$, and the content of exchangeable cations in the soil, and nutrients in the leaves, as well as, the response of the dendrometric variables, such as height, diameter, volume, increments, and timber productivity during the initial growth of eucalyptus plantations in acid soil under different doses and ways of application of limestone, gypsum, and lime mud.

\section{MATERIAL AND METHODS}

The experiment was carried out in the field, in the municipality of Bocaina do Sul/SC. The climate of the region according to the Köppen classification is $\mathrm{Cfb}$, subtropical without dry season (ALVARES et al., 2014) and a mean altitude of $860 \mathrm{~m}$. The soil of the region is originated from basalt of the Serra Geral formation, a basic volcanic rock that occupies most of the Santa Catarina Plateau (POTTER et al., 2004), and was classified as Dystrophic Humic Cambisol of clayey texture and undulating relief.

In the $0-20 \mathrm{~cm}$ layer, before the installation of the experiment, the soil presented the following characteristics, clay content: $35 \%$; organic matter: $4 \%$; $\mathrm{pH}$ (water): $4.1 ; \mathrm{Al}: 10.7 \mathrm{cmol}_{\mathrm{c}} / \mathrm{dm}^{3} ; \mathrm{Ca}: 0.25 \mathrm{cmol}_{\mathrm{c}} / \mathrm{dm}^{3}$; $\mathrm{Mg}: 0.30 \mathrm{cmol}_{\mathrm{c}} / \mathrm{dm}^{3} ; \mathrm{P}: 2.6 \mathrm{mg} / \mathrm{dm}^{3} ; \mathrm{K}: 75.5 \mathrm{mg} / \mathrm{dm}^{3} ; \mathrm{S}: 11 \mathrm{mg} / \mathrm{dm}^{3} ; \mathrm{Zn}: 0.45 \mathrm{mg} / \mathrm{dm}^{3} ; \mathrm{Cu}: 0.8 \mathrm{mg} / \mathrm{dm}^{3} ; \mathrm{B}: 0.45$ $\mathrm{mg} / \mathrm{dm}^{3}$, and $\mathrm{Mn}: 5 \mathrm{mg} / \mathrm{dm}^{3}$ and, in the $20-40 \mathrm{~cm}$ layer, clay: $38 \%$; organic matter: $3.2 \%$; $\mathrm{pH}$ (water): $4.2 ; \mathrm{Al}$ : $10.8 \mathrm{cmol}_{\mathrm{c}} / \mathrm{dm}^{3} ; \mathrm{Ca}: 0.15 \mathrm{cmol}_{\mathrm{c}} / \mathrm{dm}^{3} ; \mathrm{Mg}: 0.15 \mathrm{cmol}_{\mathrm{c}} / \mathrm{dm}^{3} ; \mathrm{P}: 1.1 \mathrm{mg} / \mathrm{dm}^{3} ; \mathrm{K}: 57.5 \mathrm{mg} / \mathrm{dm}^{3} ; \mathrm{S}: 14 \mathrm{mg} / \mathrm{dm}^{3} ; \mathrm{Zn}$ : $0.25 \mathrm{mg} / \mathrm{dm}^{3} ; \mathrm{Cu}: 0.8 \mathrm{mg} / \mathrm{dm}^{3} ; \mathrm{B}: 0.35 \mathrm{mg} / \mathrm{dm}^{3}$, and $\mathrm{Mn}: 3.5 \mathrm{mg} / \mathrm{dm}^{3}$.

According to the "Manual de Calagem e Adubação para os Estados de Rio Grande do Sul e Santa Catarina" (CQFS, 2016) it was determined the need of $5.5 \mathrm{t} \mathrm{ha}^{-1}$ of limestone to be applied to raise the pH in water from layer $0-10 \mathrm{~cm}$ to 5.2, as indicated by ALMEIDA et al. (1999). Due to a previous application of $2.0 \mathrm{tha}^{-1}$ of limestone on the surface, in the whole area, this quantity was subtracted from the total required dose. So, it was established a dose of acidity corrective at $3.5 \mathrm{t} \mathrm{ha}^{-1}$ as a reference dose of limestone to be applied. Thus, the control treatment included the application of $2 \mathrm{t} \mathrm{ha}^{-1}$ of dolomitic limestone on the surface and in total area, six months before the installation of the experiment.

The dose of gypsum was calculated to provide an equivalent quantity of half the amount of Ca added through limestone. In the experiment, the gypsum (33\% of Ca) was used as a soil conditioner, and as correctives, dolomitic limestone, with total relative neutralizing power (TRNP) of 56\% (51\% of Ca) and $1 \%$ moisture, and lime mud, with $87 \%$ TRNP and $30.5 \%$ moisture. This way, the treatments were established as described in Table 1. In treatments where correctives were not applied in the entire area, the same pre-established doses per ha were applied in a concentrated form in smaller areas, in the ridge band or planting furrow.

The treatments were arranged in complete randomized blocks with four repetitions, totaling 36 rectangular sampling units. The experimental units (EU) were composed of four planting rows spaced apart $3.5 \mathrm{~m}$, and six plants per row spaced $2.0 \mathrm{~m}$ between them. The first and fourth rows were considered as border rows, as well as the first and last plants of each row, obtaining a sample unit with eight useful plants.

Table 1. Description of the treatments with respective doses, materials, way, and area of application in the soil Tabela 1. Descrição dos tratamentos com as respectivas doses, materiais, forma e local de aplicação no solo.

\begin{tabular}{cccccc}
\hline Treatment & Dose & Equivalent dose & Material $^{\mathbf{1}}$ & Application & Area $^{\mathbf{2}}$ \\
\hline $\mathbf{1}$ & - & - & control & - & - \\
$\mathbf{2}$ & $3.5 \mathrm{tha}^{-1}$ & $3.5 \mathrm{tha}^{-1}$ & $\mathrm{CD}$ & superficial & AT \\
$\mathbf{3}$ & $1.75 \mathrm{t} \mathrm{ha}^{-1}$ & $6.1 \mathrm{tha}^{-1}$ & $\mathrm{CD}$ & superficial & $\mathrm{FP}$ \\
$\mathbf{4}$ & $3.5 \mathrm{t} \mathrm{ha}^{-1}$ & $12.3 \mathrm{tha}^{-1}$ & $\mathrm{CD}$ & superficial & $\mathrm{FP}$ \\
$\mathbf{5}$ & $3.5 \mathrm{tha}^{-1}$ & $12.3 \mathrm{tha}^{-1}$ & LC & superficial & $\mathrm{FP}$
\end{tabular}

FLORESTA, Curitiba, PR, v. 50, n. 4, p. 1788 - 1797, out/dez 2020.

Pfleger, P. et.al.

ISSN eletrônico 1982-4688

DOI: 10.5380/rf.v50 i4. 65682 


\begin{tabular}{lccccc}
$\mathbf{6}$ & $3.5 \mathrm{tha}^{-1}+2.75 \mathrm{tha}^{-1}$ & $12.3 \mathrm{tha}^{-1}+9.6 \mathrm{tha}^{-1}$ & $\mathrm{CD}+\mathrm{GE}$ & superficial & $\mathrm{FP}$ \\
$\mathbf{7}$ & $1.75 \mathrm{tha}^{-1}$ & $20.4 \mathrm{tha}^{-1}$ & $\mathrm{DC}$ & incorporated & $\mathrm{SP}$ \\
$\mathbf{8}$ & $1.75 \mathrm{tha}^{-1}+1.38 \mathrm{tha}^{-1}$ & $20.4 \mathrm{tha}^{-1}+16.0 \mathrm{tha}^{-1}$ & $\mathrm{CD}+\mathrm{GE}$ & incorporated & $\mathrm{SP}$ \\
$\mathbf{9}$ & $1.38 \mathrm{tha}^{-1}$ & $16.0 \mathrm{tha}^{-1}$ & $\mathrm{GE}$ & incorporated & $\mathrm{SP}$ \\
\hline
\end{tabular}

${ }^{1} \mathrm{CD}=$ dolomitic limestone, $\mathrm{LC}=$ lime mud, $\mathrm{GE}=$ gypsum. ${ }^{2} \mathrm{AT}=$ total area, $\mathrm{FP}=$ ridge band, $\mathrm{SP}=$ planting furrow.

The planting was carried out in October 2015 using clonal seedlings of Eucalyptus dunnii (CL7003), endemic to Australia. The treatments were applied in April 2016, after the initial establishment of the plants, as it was considered the best area available for the study. The correctives were distributed manually in the surface. In the planting furrow after opened with a hoe, the products were distributed manually, and the previously removed soil was used to close the furrow.

Mineral fertilization with N, P, and K (ammonium nitrate, triple superphosphate, and potassium chloride, respectively) was performed equally, three applications, in each treatment. The first $200 \mathrm{~g}$ per plant $(04-26-06)$ were applied 10 days after planting, the second $200 \mathrm{~g}$ per plant $(15-00-30) 90$ days after planting, and the third $150 \mathrm{~g}$ per plant $(10-05-30) 365$ days after planting.

The seedlings were planted with $3.5 \mathrm{~m}$ between rows and 2.0 between plants, in a second-rotation area, which received initial tillage by a track-type tractor, and a moldboard plow with a shank with negative angle (until $0,5 \mathrm{~m}$ depth), and two pairs of discs plowers, forming a preparation range with $1 \mathrm{~m}$ width.

Nine months after starting the treatments, water $\mathrm{pH}$ and content of exchangeable cations were determined in the soil layers 0 to $20 \mathrm{~cm}$ and 20 to $40 \mathrm{~cm}$. The samples, collected with a dutch auger, were composed of four subsampling points located in the planting rows of the seedlings. Twelve months after planting, three fully developed leaves were collected from the half of the middle third of the canopy in each quadrant (North, South, East, West), from three medium-sized trees, totaling 12 leaves per plant and 36 leaves per EU. The leaves were oven-dried at $65^{\circ} \mathrm{C}$ until constant mass, ground in a processor, and then, the total contents of $\mathrm{N}, \mathrm{P}, \mathrm{K}, \mathrm{Ca}$, and $\mathrm{Mg}$ were analyzed. The analyzes were performed according to the methodology described by Tedesco et al. (1995).

Measurements such as height and circumference at breast height $(\mathrm{CBH})$ were carried out in all useful plants in each plot with a ruler and a tape measure at 12 months after planting $(6$ months after treatment application). Subsequently, the CBH was converted in diameter at breast height (DBH). At 15 and 24 months, new measurements were performed, with a hypsometer (due to trees height) and tape measure, respectively.

The volume of timber was estimated from height and DBH data through the form factor method (MIRANDA et al., 2015), because it was a population at the initial growth, and by the impossibility to cut some individuals to adjust a volumetric model (Formula 1).

$$
V=\pi \frac{D B H^{2}}{4} h f \quad \text { Formula } 1
$$

Where: $\mathrm{V}=$ volume $\left(\mathrm{m}^{3}\right) ; \pi=\mathrm{Pi}(3.1416) ; \mathrm{DBH}=$ diameter at breast height $(\mathrm{cm})$, measured at 1.3 meters from the soil surface; $\mathrm{h}=$ tree height $(\mathrm{m}) ; f=$ form factor. The value of the form factor used was 0.48 , an average established according to the values found in the literature for other species since there is no estimated value for the used species yet (MIRANDA et al., 2015; AZEVEDO et al., 2011; MIGUEL et al., 2010).

Considering the space between plants of $3.5 \times 2.0 \mathrm{~m}\left(7.0 \mathrm{~m}^{2}\right)$, it was obtained a density of 1429 plants per hectare. Hence, the individual's volume was multiplied by the plant density estimating the volume that would be found per hectare in each treatment. The current annual increment (CAI) was obtained by the difference between the volume of the chosen year and the volume of the previous year. The mean annual increment (MAI) was calculated by the relation between the total volume and the population age, both determined for the second year only, considering that in the first year the CAI and MAI are equal to the volume of the first year (12 months).

It was performed the analysis of variance and Tukey's test at 5\% significance for all variables evaluated, using software R 3.3.1 (R CORE TEAM, 2016).

\section{RESULTS}

\section{Content of exchangeable cations and soil pH}

After installing the treatments, in January 2017, the application of limestone incorporated in the seedlings planting furrow (T7) increased significantly the $\mathrm{pH}$ by $37 \%$ in the $0-20 \mathrm{~cm}$ layer, and $17 \%$ in the $20-40 \mathrm{~cm}$ layer, reaching values of 5.5 and 4.8, respectively (Table 2). It was the only treatment that altered the $\mathrm{pH}$ significantly compared to the control treatment (T1) within the study period. The limestone application incorporated in the planting furrow (T7) and with gypsum (T8) were effective in the reduction of exchangeable Al in both depths, reducing by $89 \%$ and $80 \%$ in the layer $0-20 \mathrm{~cm}$ and $69 \%$ and $47 \%$, in the layer $20-40 \mathrm{~cm}$, respectively. 
Table 2. Value of $\mathrm{pH}$ and content of exchangeable cations of Humic Cambisol nine months after applying limestone, gypsum, and lime mud in different doses and ways of application.

Tabela 2. Valor de pH e teores de cátions trocáveis de Cambissolo Húmico nove meses após aplicação de calcário, gesso e lama de cal em diferentes doses e formas de aplicação.

\begin{tabular}{|c|c|c|c|c|c|c|}
\hline \multirow{2}{*}{ Treatment $^{1}$} & \multirow{2}{*}{$\begin{array}{c}\text { Water } \\
\text { pH }\end{array}$} & Al & $\mathbf{C a}$ & $\mathrm{Mg}$ & $\mathbf{K}$ & $\mathbf{N a}$ \\
\hline & & \multicolumn{5}{|c|}{$\mathrm{cmol}_{\mathrm{c}} / \mathrm{dm}^{3}$} \\
\hline \multicolumn{7}{|c|}{$0-20 \mathrm{~cm}$} \\
\hline Control & $4.0 \mathrm{bc}$ & $9.8 \mathrm{a}$ & $0.83 \mathrm{~d}$ & $1.54 \mathrm{~d}$ & $0.99 \mathrm{a}$ & $0.07 \mathrm{~b}$ \\
\hline $3.5 \mathrm{tha}^{-1}$ of $\mathrm{CD} / \mathrm{S} / \mathrm{AT}$ & $4.3 \mathrm{bc}$ & $8.0 \mathrm{a}$ & $4.18 \mathrm{~cd}$ & $4.05 \mathrm{c}$ & $0.64 \mathrm{a}$ & $0.06 \mathrm{~b}$ \\
\hline $1.75 \mathrm{tha}^{-1}$ of $\mathrm{CD} / \mathrm{S} / \mathrm{FP}$ & $4.3 \mathrm{bc}$ & $7.4 \mathrm{a}$ & $3.47 \mathrm{~cd}$ & $4.05 \mathrm{c}$ & $0.65 \mathrm{a}$ & $0.06 \mathrm{~b}$ \\
\hline $3.5 \mathrm{t} \mathrm{ha}^{-1}$ of $\mathrm{CD} / \mathrm{S} / \mathrm{FP}$ & $4.3 \mathrm{bc}$ & $6.5 \mathrm{ab}$ & $4.34 \mathrm{~cd}$ & $4.94 \mathrm{bc}$ & $0.84 \mathrm{a}$ & $0.06 \mathrm{~b}$ \\
\hline $3.5 \mathrm{t} \mathrm{ha}^{-1}$ of $\mathrm{LC} / \mathrm{S} / \mathrm{FP}$ & $4.5 \mathrm{bc}$ & $6.6 \mathrm{ab}$ & $4.72 \mathrm{bcd}$ & $1.49 \mathrm{~d}$ & $0.79 \mathrm{a}$ & $0.17 \mathrm{a}$ \\
\hline $\begin{array}{c}3.5 \mathrm{tha}^{-1} \text { of CD/S/FP }+2.75 \mathrm{tha}^{-1} \text { of } \\
\text { GE/S/FP }\end{array}$ & $4.3 \mathrm{bc}$ & $6.3 \mathrm{ab}$ & $6.09 \mathrm{abcd}$ & $4.98 \mathrm{bc}$ & $0.66 \mathrm{a}$ & $0.05 \mathrm{~b}$ \\
\hline $1.75 \mathrm{t} \mathrm{ha}^{-1}$ of CD/I/SP & $5.5 \mathrm{a}$ & $1.1 \mathrm{c}$ & $12.21 \mathrm{a}$ & $7.83 \mathrm{a}$ & $0.90 \mathrm{a}$ & $0.08 \mathrm{ab}$ \\
\hline $\begin{array}{c}1.75 \mathrm{t} \mathrm{ha}^{-1} \text { of } \mathrm{CD} / \mathrm{I} / \mathrm{SP}+1.38 \mathrm{tha}^{-1} \text { of } \\
\text { GE/I/SP }\end{array}$ & $4.7 \mathrm{~b}$ & $2.0 \mathrm{bc}$ & $11.40 \mathrm{ab}$ & $7.31 \mathrm{ab}$ & $0.91 \mathrm{a}$ & $0.09 \mathrm{ab}$ \\
\hline $1.38 \mathrm{t} \mathrm{ha}^{-1}$ of GE/I/SP & $3.8 \mathrm{c}$ & $9.9 \mathrm{a}$ & $8.04 \mathrm{abc}$ & $1.30 \mathrm{~d}$ & $0.84 \mathrm{a}$ & $0.09 \mathrm{ab}$ \\
\hline \multicolumn{7}{|c|}{$20-40 \mathrm{~cm}$} \\
\hline Control & $4.0 \mathrm{~b}$ & $11.0 \mathrm{a}$ & $0.39 \mathrm{c}$ & $1.22 \mathrm{c}$ & $0.62 \mathrm{a}$ & $0.07 \mathrm{ab}$ \\
\hline $3.5 \mathrm{tha}^{-1}$ of CD/S/AT & $4.1 \mathrm{~b}$ & $9.6 \mathrm{ab}$ & $1.59 \mathrm{c}$ & $2.45 \mathrm{bc}$ & $0.47 \mathrm{a}$ & $0.05 \mathrm{ab}$ \\
\hline $1.75 \mathrm{t} \mathrm{ha}^{-1}$ of $\mathrm{CD} / \mathrm{S} / \mathrm{FP}$ & $4.1 \mathrm{~b}$ & $9.1 \mathrm{ab}$ & $1.53 \mathrm{c}$ & $2.99 \mathrm{bc}$ & $0.44 \mathrm{a}$ & $0.05 \mathrm{ab}$ \\
\hline $3.5 \mathrm{t} \mathrm{ha}^{-1}$ of $\mathrm{CD} / \mathrm{S} / \mathrm{FP}$ & $4.1 \mathrm{~b}$ & $9.0 \mathrm{ab}$ & $1.83 \mathrm{c}$ & $3.21 \mathrm{bc}$ & $0.50 \mathrm{a}$ & $0.05 \mathrm{ab}$ \\
\hline $3.5 \mathrm{tha}^{-1}$ of $\mathrm{LC} / \mathrm{S} / \mathrm{FP}$ & $4.0 \mathrm{~b}$ & $10.3 \mathrm{ab}$ & $1.06 \mathrm{c}$ & $0.74 \mathrm{c}$ & $0.62 \mathrm{a}$ & $0.08 \mathrm{a}$ \\
\hline $\begin{array}{c}3.5 \mathrm{tha}^{-1} \text { of } \mathrm{CD} / \mathrm{S} / \mathrm{FP}+2.75 \mathrm{tha}^{-1} \text { of } \\
\text { GE/S/FP }\end{array}$ & $4.0 \mathrm{~b}$ & $7.7 \mathrm{abc}$ & $3.74 \mathrm{abc}$ & $4.09 \mathrm{ab}$ & $0.43 \mathrm{a}$ & $0.04 \mathrm{ab}$ \\
\hline $1.75 \mathrm{t} \mathrm{ha}^{-1}$ of CD/I/SP & $4.8 \mathrm{a}$ & $3.4 \mathrm{c}$ & $7.82 \mathrm{ab}$ & $6.61 \mathrm{a}$ & $0.64 \mathrm{a}$ & $0.06 \mathrm{ab}$ \\
\hline $\begin{array}{c}1.75 \mathrm{t} \mathrm{ha}^{-1} \text { of CD/I/SP }+1.38 \mathrm{tha}^{-1} \text { of } \\
\text { GE/I/SP }\end{array}$ & $4.2 \mathrm{~b}$ & $5.8 \mathrm{bc}$ & $8.37 \mathrm{a}$ & $6.62 \mathrm{a}$ & $0.62 \mathrm{a}$ & $0.04 \mathrm{~b}$ \\
\hline $1.38 \mathrm{t} \mathrm{ha}^{-1}$ of GE/I/SP & $3.8 \mathrm{~b}$ & $10.9 \mathrm{a}$ & $2.90 \mathrm{bc}$ & $0.73 \mathrm{c}$ & $0.68 \mathrm{a}$ & $0.06 \mathrm{ab}$ \\
\hline
\end{tabular}

${ }^{1} \mathrm{CD}$ - dolomite limestone; $\mathrm{S}$ - surface; AT - total area; FP - ridge band; LC - lime mud; GE - gypsum; I - incorporated; SP - planting furrow.

The $\mathrm{Ca}$ contents in the soil showed significant increments after applications of limestone incorporated in the planting furrow (T7 $-1.371 \%)$, limestone and gypsum (T8 - 1.273\%), and gypsum (T9-869\%), in relation to the control treatment (T1), in layer $0-20 \mathrm{~cm}$. In the $20-40 \mathrm{~cm}$ layer, the same treatments increased Ca contents by $1,905 \%$ (T7), and 2,046\% (T8), except for the application of gypsum (T9). Unlike Ca, Mg content increased significantly up to $408 \%$ by the application of limestone, regardless the dose and way of application in the $0-20$ $\mathrm{cm}$ layer. However, in greater depth $(20-40 \mathrm{~cm})$, higher doses of limestone combined with higher doses of gypsum (T6), and limestone combined with and without gypsum (T7 and T8), were more efficient. Although the application of the lime mud did not influence the soil acidity, exchangeable contents of $\mathrm{Al}, \mathrm{Ca}$ and $\mathrm{Mg}$, its presence increased significantly the content of $\mathrm{Na}$ in the $0-20 \mathrm{~cm}$ layer. Regarding $\mathrm{K}$, it was not influenced by any application within the $40 \mathrm{~cm}$ of the evaluated profile.

\section{Height, diameter, and estimated timber volume}

At 12th month, the use of $1.75 \mathrm{tha}^{-1}$ of limestone on the surface in the ridge band (T3) provided a higher mean in the height of the trees when compared to limestone and gypsum in the furrow (T8), and gypsum in the furrow (T9), with a difference of $9.6 \%$ and $11.5 \%$, respectively (Table 3). However, at the 15th month of planting, the use of $3.5 \mathrm{t} \mathrm{ha}^{-1}$ of lime mud applied at the surface in the ridge band (T5) resulted in a greater height, where the mean was $5.32 \mathrm{~m}$ providing an increment of $8.4 \%$ in height in relation to the control treatment (T1), showing that the treatment favors the initial vertical growth of the species. The gypsum in the planting furrow (T9) did not change the growth of the plants and was the treatment with the lowest height among the others, with a mean of $4.67 \mathrm{~m}$. This increment in height after 3 months, was the same compared to the control treatment (T1), showing that the isolated use has no advantages to the plant. There was no significant effect of applying the correctives in the soil on plant height growth at the 24th month evaluation. 
Table 3. Means of height and diameter at breast height (DBH) of Eucalyptus dunnii at 12, 15, and 24 months, grown in Humic Cambisol with limestone, gypsum, and lime mud in different doses and ways of application.

Tabela 3. Altura média e diâmetro à altura do peito (DAP) médio de plantas de Eucalyptus dunnii aos 12,15 e 24 meses de idade cultivadas em Cambissolo Húmico com aplicação de calcário, gesso e lama de cal em diferentes doses e formas de aplicação.

\begin{tabular}{|c|c|c|c|c|c|c|}
\hline \multirow[b]{2}{*}{ Treatment $^{1}$} & \multicolumn{3}{|c|}{ Height (m) } & \multicolumn{3}{|c|}{ DBH (cm) } \\
\hline & $\begin{array}{c}12 \\
\text { months }\end{array}$ & $\begin{array}{c}15 \\
\text { months }\end{array}$ & $\begin{array}{c}24 \\
\text { months }\end{array}$ & $\begin{array}{c}12 \\
\text { months }\end{array}$ & $\begin{array}{c}15 \\
\text { months }\end{array}$ & $\begin{array}{c}24 \\
\text { months }\end{array}$ \\
\hline Control & $2.95 \mathrm{ab}$ & $4.91 \mathrm{bc}$ & $8.84 \mathrm{a}$ & $2.42 \mathrm{bc}$ & $5.45 \mathrm{ab}$ & $8.95 \mathrm{a}$ \\
\hline $3.5 \mathrm{t} \mathrm{ha}^{-1}$ of CD/S/AT & $3.02 \mathrm{ab}$ & $5.06 \mathrm{ab}$ & $8.87 \mathrm{a}$ & $2.78 \mathrm{ab}$ & $5.78 \mathrm{ab}$ & $9.08 \mathrm{a}$ \\
\hline $1.75 \mathrm{t} \mathrm{ha}^{-1}$ of $\mathrm{CD} / \mathrm{S} / \mathrm{FP}$ & $3.19 \mathrm{a}$ & $5.14 \mathrm{ab}$ & $9.00 \mathrm{a}$ & $2.97 \mathrm{a}$ & $6.04 \mathrm{a}$ & $9.35 \mathrm{a}$ \\
\hline $3.5 \mathrm{t} \mathrm{ha}^{-1}$ of $\mathrm{CD} / \mathrm{S} / \mathrm{FP}$ & $3.01 \mathrm{ab}$ & $4.91 \mathrm{bc}$ & $8.59 \mathrm{a}$ & $2.50 \mathrm{bc}$ & $5.61 \mathrm{ab}$ & $8.86 \mathrm{a}$ \\
\hline $3.5 \mathrm{t} \mathrm{ha}^{-1}$ of $\mathrm{LC} / \mathrm{S} / \mathrm{FP}$ & $2.99 \mathrm{ab}$ & $5.32 \mathrm{a}$ & $8.59 \mathrm{a}$ & $2.53 \mathrm{abc}$ & $5.47 \mathrm{ab}$ & $8.59 \mathrm{a}$ \\
\hline $\begin{array}{c}3.5 \mathrm{t} \mathrm{ha}^{-1} \text { of } \mathrm{CD} / \mathrm{S} / \mathrm{FP}+2.75 \mathrm{tha}^{-1} \text { of } \\
\text { GE/S/FP }\end{array}$ & $3.09 \mathrm{ab}$ & $5.15 \mathrm{ab}$ & $8.88 \mathrm{a}$ & $2.70 \mathrm{abc}$ & $5.85 \mathrm{a}$ & $9.07 \mathrm{a}$ \\
\hline $1.75 \mathrm{t} \mathrm{ha}^{-1}$ of CD/I/SP & $3.08 \mathrm{ab}$ & $5.02 \mathrm{abc}$ & $8.97 \mathrm{a}$ & $2.70 \mathrm{abc}$ & $5.73 \mathrm{ab}$ & $8.97 \mathrm{a}$ \\
\hline $\begin{array}{c}1.75 \mathrm{t} \mathrm{ha}^{-1} \text { of CD/I/SP }+1.38 \mathrm{tha}^{-1} \text { of } \\
\text { GE/I/SP }\end{array}$ & $2.91 \mathrm{~b}$ & $5.00 \mathrm{abc}$ & $8.54 \mathrm{a}$ & $2.55 \mathrm{abc}$ & $5.51 \mathrm{ab}$ & $9.13 \mathrm{a}$ \\
\hline $1.38 \mathrm{t} \mathrm{ha}^{-1}$ of GE/I/SP & $2.86 \mathrm{~b}$ & $4.67 \mathrm{c}$ & $8.67 \mathrm{a}$ & $2.28 \mathrm{c}$ & $5.15 \mathrm{~b}$ & $8.69 \mathrm{a}$ \\
\hline
\end{tabular}

Same letters in the column do not differ significantly by Tukey test at $5 \%$ of significance. ${ }^{1} \mathrm{CD}$ - dolomite limestone; $\mathrm{S}-\mathrm{surface}$; AT - total area; FP - ridge band; LC - lime mud; GE - gypsum; I - incorporated; SP - planting furrow.

Similar to height, significant differences were observed for growth in diameter only at 12 and 15 months of planting, without distinction between treatments at 24 months. The limestone applied at a lower dose in the surface (T3) favored the growth in diameter of $23 \%$ in relation to the control treatment (T1) in the evaluation performed at 12 months of planting. Other doses and forms of application of limestone, lime mud, and gypsum did not promote significant improvements in plant growth diameter compared to control treatment (T1). For instance, the isolated gypsum in the furrow (T9), presented again the lowest values, $6 \%$ under than that found in the control treatment (T1).

At 15 months of planting, the application of soil correctives, in general, showed no differences in the diameter increase of the plants. Except for the application of limestone in the surface (T3), and limestone and gypsum in the surface (T6) with increase of 17\% and 14\%, respectively, comparing to gypsum in the furrow (T9). During the experiment, there was a reduction in the differences between treatments. At 24 months, there was no longer a significant difference between treatments, although the surface liming (T3) still have a higher mean number (4\% higher than control).

Productivity was evaluated by the volume of timber per hectare at 12, 15, and 24 months, and by the current annual increment (CAI), and mean annual increment (MAI) at 24 months (Table 4). There was an increase of $64 \%$ in volume at 12 months after applying $1.75 \mathrm{t} \mathrm{ha}^{-1}$ of limestone in the ridge band (T3) in relation to the control. However, the other doses and ways of application of limestone, lime mud, and gypsum did not significantly increase the estimated volume per hectare at 12 months.

At 15 months, there was no difference between the estimated volume per hectare in any of the treatments and control (T1). Therefore, a significant difference of $49.9 \%$ was observed in the application of $1.75 \mathrm{t} \mathrm{ha}^{-1}$ of limestone in the ridge band (T3), and $41 \%$ with $3.5 \mathrm{t} \mathrm{ha}^{-1}$ of limestone with $2.75 \mathrm{t} \mathrm{ha}^{-1}$ of gypsum in the ridge band (T6), in relation to the application of $1.38 \mathrm{t} \mathrm{ha}^{-1}$ of gypsum in the planting furrow (T9), which presented the lower value in volume $\left(6.74 \mathrm{~m}^{3} \mathrm{ha}^{-1}\right)$. Nevertheless, at 24 months of cultivation, the plants did not show significant differences in the increment in volume.

Table 4. Timber volume estimated at 12, 15 and 24 months of age, current annual increment (CAI) and mean annual increment (MAI) at 24 months of age of Eucalyptus dunnii grown in Humic Cambisol with limestone, gypsum and lime mud applied in different doses and ways of applications.

Tabela 4. Volume de madeira estimado aos 12, 15 e 24 meses de idade, incremento corrente anual (ICA) e incremento médio anual (IMA) aos 24 meses de idade de Eucalyptus dunnii cultivado em Cambissolo Húmico com aplicação de calcário, gesso e lama de cal em diferentes doses e formas de aplicação.

\begin{tabular}{lccc}
\hline Treatment $^{1}$ & Volume $\left(\mathbf{m}^{3} / \mathbf{h a}\right)$ & $\begin{array}{c}\text { CAI } \\
\left(\mathbf{m}^{3} / \mathbf{h a}\right)\end{array}$ & $\begin{array}{c}\text { MAI } \\
\left(\mathbf{m}^{3} / \mathbf{h a}\right)\end{array}$ \\
\hline
\end{tabular}

FLORESTA, Curitiba, PR, v. 50, n. 4, p. 1788 - 1797, out/dez 2020.

Pfleger, P. et.al.

ISSN eletrônico 1982-4688 


\begin{tabular}{|c|c|c|c|c|c|}
\hline & $\begin{array}{c}12 \\
\text { months }\end{array}$ & $\begin{array}{c}15 \\
\text { months }\end{array}$ & $\begin{array}{c}24 \\
\text { months }\end{array}$ & $\begin{array}{c}24 \\
\text { months }\end{array}$ & $\begin{array}{c}24 \\
\text { months }\end{array}$ \\
\hline Control & $0.931 \mathrm{bc}$ & $7.84 \mathrm{ab}$ & $38.1 \mathrm{a}$ & $37.2 \mathrm{a}$ & $19.0 \mathrm{a}$ \\
\hline $3.5 \mathrm{t} \mathrm{ha}^{-1}$ of $\mathrm{CD} / \mathrm{S} / \mathrm{AT}$ & $1.25 \mathrm{ab}$ & $9.15 \mathrm{ab}$ & $39.3 \mathrm{a}$ & $38.1 \mathrm{a}$ & $19.7 \mathrm{a}$ \\
\hline $1.75 \mathrm{t} \mathrm{ha}^{-1}$ of $\mathrm{CD} / \mathrm{S} / \mathrm{FP}$ & $1.53 \mathrm{a}$ & $10.1 \mathrm{a}$ & $42.4 \mathrm{a}$ & $40.9 \mathrm{a}$ & $21.2 \mathrm{a}$ \\
\hline $3.5 \mathrm{tha}^{-1}$ of $\mathrm{CD} / \mathrm{S} / \mathrm{FP}$ & $1.02 \mathrm{bc}$ & $8.33 \mathrm{ab}$ & $36.6 \mathrm{a}$ & $35.6 \mathrm{a}$ & $18.3 \mathrm{a}$ \\
\hline $3.5 \mathrm{t} \mathrm{ha}^{-1}$ of $\mathrm{LC} / \mathrm{S} / \mathrm{FP}$ & $1.04 \mathrm{bc}$ & $8.62 \mathrm{ab}$ & $34.1 \mathrm{a}$ & $33.1 \mathrm{a}$ & $17.1 \mathrm{a}$ \\
\hline $\begin{array}{c}3.5 \mathrm{tha}^{-1} \text { of CD/S/FP }+2.75 \mathrm{tha}^{-1} \text { of } \\
\text { GE/S/FP }\end{array}$ & $1.22 \mathrm{abc}$ & $9.51 \mathrm{a}$ & $39.4 \mathrm{a}$ & $38.2 \mathrm{a}$ & $19.7 \mathrm{a}$ \\
\hline $1.75 \mathrm{t} \mathrm{ha}^{-1}$ of CD/I/SP & $1.22 \mathrm{abc}$ & $8.91 \mathrm{ab}$ & $39.1 \mathrm{a}$ & $37.8 \mathrm{a}$ & $19.5 \mathrm{a}$ \\
\hline $\begin{array}{c}1.75 \mathrm{t} \mathrm{ha}^{-1} \text { of CD/I/SP }+1.38 \mathrm{tha}^{-1} \text { of } \\
\text { GE/I/SP }\end{array}$ & $1.03 \mathrm{bc}$ & $8.17 \mathrm{ab}$ & $38.2 \mathrm{a}$ & $37.2 \mathrm{a}$ & $19.1 \mathrm{a}$ \\
\hline $1.38 \mathrm{tha}^{-1}$ of GE/I/SP & $0.812 \mathrm{c}$ & $6.74 \mathrm{~b}$ & $35.5 \mathrm{a}$ & $34.7 \mathrm{a}$ & $17.8 \mathrm{a}$ \\
\hline
\end{tabular}

Same letters in the column do not differ significantly by Tukey test at $5 \%$ of significance. $1 \mathrm{CD}$ - dolomite limestone; $\mathrm{S}-$ surface; AT - total area; FP - ridge band; LC - lime mud; GE - agricultural gypsum; I - incorporated; SP - planting furrow.

Nutritional status of the plants

In the leaves, there was no significant difference in the analyzed nutrient contents after the application of limestone, lime mud, and gypsum, at 12 months of cultivation, regardless of dose and way of application (Table 5). The content of $\mathrm{N}$ did not exceed $2 \%$ in the leave, placing it between $1.94 \%$ with superficial application of limestone in total area (T2), and 1.64\% with limestone applied on the surface at the ridge band (T4). Phosphorus was the element of lowest proportion among the others macronutrients analyzed, with an average of $0.147 \%$. Potassium showed a higher percentage, but not higher than $\mathrm{N}$, ranging from 1.10 to $1.27 \%$. Calcium ranged from 0.22 to $0.28 \%$ and $\mathrm{Mg}$ from 0.15 to $0.19 \%$. The contents followed the order of $\mathrm{N}>\mathrm{K}>\mathrm{Ca}>\mathrm{Mg}>\mathrm{P}$. Although not significant, we can observe an increasing trend in the leaf contents of Ca with the application of lime mud (T5), limestone plus gypsum in the surface (T6), and limestone plus gypsum in the planting furrow (T8).

Table 5. Contents of nitrogen $(\mathrm{N})$, phosphorus $(\mathrm{P})$, potassium $(\mathrm{K})$, calcium $(\mathrm{CA})$, and magnesium $(\mathrm{Mg})$ determined in the leaf tissue of a 12-months old Eucalyptus dunnii, cultivated in Humic Cambisol with application of limestone, gypsum, and lime mud in different doses and ways of applications.

Tabela 5. Teores de nitrogênio $(\mathrm{N})$, fósforo $(\mathrm{P})$, potássio $(\mathrm{K})$, cálcio $(\mathrm{Ca})$ e magnésio $(\mathrm{Mg})$ determinados em tecido foliar de Eucalyptus dunnii com 12 meses de idade, cultivados em Cambissolo Húmico com aplicação de calcário, gesso e lama de cal em diferentes doses e formas de aplicação.

\begin{tabular}{|c|c|c|c|c|c|}
\hline Treatmonts 1 & $\mathbf{N}$ & $\mathbf{P}$ & $\mathbf{K}$ & Ca & Mg \\
\hline & & & & & \\
\hline Control & $1.88 \mathrm{a}$ & $0.143 \mathrm{a}$ & $1.21 \mathrm{a}$ & $0.223 \mathrm{a}$ & $0.185 \mathrm{a}$ \\
\hline $3.5 \mathrm{t} \mathrm{ha}^{-1}$ of $\mathrm{CD} / \mathrm{S} / \mathrm{AT}$ & $1.94 \mathrm{a}$ & $0.143 \mathrm{a}$ & $1.14 \mathrm{a}$ & $0.215 \mathrm{a}$ & $0.185 \mathrm{a}$ \\
\hline $1.75 \mathrm{tha}^{-1}$ of $\mathrm{CD} / \mathrm{S} / \mathrm{FP}$ & $1.77 \mathrm{a}$ & $0.145 \mathrm{a}$ & $1.17 \mathrm{a}$ & $0.258 \mathrm{a}$ & $0.178 \mathrm{a}$ \\
\hline $3.5 \mathrm{tha}^{-1}$ of $\mathrm{CD} / \mathrm{S} / \mathrm{FP}$ & $1.64 \mathrm{a}$ & $0.143 \mathrm{a}$ & $1.10 \mathrm{a}$ & $0.250 \mathrm{a}$ & $0.173 \mathrm{a}$ \\
\hline $3.5 \mathrm{tha}^{-1}$ of LC/S/FP & $1.74 \mathrm{a}$ & $0.145 \mathrm{a}$ & $1.24 \mathrm{a}$ & $0.275 \mathrm{a}$ & $0.173 \mathrm{a}$ \\
\hline $3.5 \mathrm{tha}^{-1}$ of CD/S/FP + $2.75 \mathrm{tha}^{-1}$ of GE/S/FP & $1.77 \mathrm{a}$ & $0.150 \mathrm{a}$ & $1.27 \mathrm{a}$ & $0.275 \mathrm{a}$ & $0.173 \mathrm{a}$ \\
\hline $1.75 \mathrm{tha}^{-1}$ of $\mathrm{CD} / \mathrm{I} / \mathrm{SP}$ & $1.93 \mathrm{a}$ & $0.160 \mathrm{a}$ & $1.19 \mathrm{a}$ & $0.218 \mathrm{a}$ & $0.170 \mathrm{a}$ \\
\hline $1.75 \mathrm{tha}^{-1}$ of $\mathrm{CD} / \mathrm{I} / \mathrm{SP}+1.38 \mathrm{tha}^{-1}$ of GE/I/SP & $1.77 \mathrm{a}$ & $0.143 \mathrm{a}$ & $1.15 \mathrm{a}$ & $0.273 \mathrm{a}$ & $0.153 \mathrm{a}$ \\
\hline $1.38 \mathrm{t} \mathrm{ha}^{-1}$ of GE/I/SP & $1.90 \mathrm{a}$ & $0.145 \mathrm{a}$ & $1.19 \mathrm{a}$ & $0.223 \mathrm{a}$ & $0.150 \mathrm{a}$ \\
\hline mean & 1.82 & 0.147 & 1.18 & 0.246 & 0.171 \\
\hline
\end{tabular}

Same letters in the column do not differ significantly by Tukey test at $5 \%$ of significance. $1 \mathrm{CD}$ - dolomite limestone; $\mathrm{S}$ - surface; AT - total area; FP - ridge band; LC - lime mud; GE - gypsum; I - incorporated; SP - planting furrow.

\section{DISCUSSION}

\section{Content of exchangeable cations and soil pH}

The results obtained regarding the correction of soil acidity and reduction of exchangeable Al contents are due to the concentration of the product in a smaller area, in addition to its incorporation, which contributed to its effect throughout the evaluated depth. Despite being the best profile correction compared to surface applications, its correction is limited to the planting furrow range, where the samples of soil were extracted, being 
a smaller treated area compared to other treatments. However, we must consider the root growth that covers larger areas, adjacent and with no corrective, as well as the long-term action of the correctives applied at the surface, that can show results over the years.

The same applies in relation to the increments in Ca contents in the soil, where there was an increase in the treatments concentrated in the furrow and incorporated, both for limestone, limestone and gypsum, and isolated gypsum. The contents increase as the amount of product applied increases, as observed by Medeiros et al. (2013). However, treatments with surface application may show medium and long-term results forming a content gradient along the profile from the surface.

The increase in $\mathrm{Mg}$ levels with the application of limestone, regardless of the dose and application way was already expected, since the limestone used was dolomite, with the presence of $\mathrm{Mg}$ in its composition. However, its presence in depth of $20-40 \mathrm{~cm}$ only occurred with higher-doses of limestone and gypsum combined, in addition to the incorporated forms of limestone. Regarding the high dose of limestone applied, combined with a high-dose of gypsum at the surface, the great quantity increases the content of $\mathrm{Ca}$ in the solution of the soil, which can increase the leaching of other minerals, such as $\mathrm{Mg}$, in the soil profile. In addition, the incorporation allows the limestone to reach deeper layers increasing the $\mathrm{Mg}$ content by its presence.

The application of lime mud did not change the chemical attributes studied, except the Na content evaluated during the experiment. However, it is important to point out that, although not significant, there was a change in numerical values, which may be significant in the medium and long-term, the same way as the other treatments studied. This alteration regarding the content of $\mathrm{Na}$ is given by the presence of this cation in the composition of the material, originated from chemical reactions from the recovery of the cooking liquor of the pulp and paper industry.

Medeiros et al. (2013) also compared the alkaline waste of the pulp industry with limestone and found that the two correctives add basic cations to the soil, besides increasing the $\mathrm{pH}$. Lima et al. (2017) also studied the effects of lime mud, and found that added to fertilizer, its application improved the $\mathrm{Ca}$ and $\mathrm{Mg}$ contents in the soil, which is recommended to replace limestone.

\section{Height, diameter, and estimated volume}

Considering the growth in height, diameter, and volume of timber in the present study, there were no great differences between treatments at 12 and 15 months, and no response at 24 months. These results may be related to the practice, carried out by the company, of applying $2 \mathrm{t} \mathrm{ha}^{-1}$ of limestone to the Ca supply. This amount of limestone applied may have favored the improvement of soil chemical attributes, such as reduction of exchangeable $\mathrm{Al}$, favoring growth and metabolism of the roots, and increase of $\mathrm{Ca}$ and $\mathrm{Mg}$ supply. Furthermore, the root growth of the culture is not limited to the soil surface layer, treated with acidity corrective, but reaches greater depths and areas of adjacent treatments exploring larger volume of soil. On the other hand, it is possible that higher doses of soil correctives may be acting negatively in the availability of nutrients, restricting the growth of the plants.

Increases in DBH and height of seedlings of E. grandis $x$ E. urophylla plants in response to doses up to $302 \mathrm{~g} \mathrm{pit}^{-1}$ of limestone applied in the planting pits in an Ferralsols were also observed by Rocha et al. (2008) which was explained by better chemical conditioning of the soil, provided by this dose. However, at doses greater than $315 \mathrm{~g} \mathrm{pit}^{-1}$ of limestone, these authors observed a decrease in plant growth. This decrease was attributed to the possible imbalance between the $\mathrm{Ca}, \mathrm{Mg}$ and $\mathrm{K}$ cations, due to the excessive limestone, which can be reflected in antagonism between them in the process of absorption by the roots. They also related that decrease to the lower availability of micronutrients due to the exaggerated increase in $\mathrm{pH}$ caused by the excess of limestone.

Vicente Ferraz et al. (2016) also observed the mean annual increment of the eucalyptus in treatments with sewage mud and limestone greater than in the control treatment, but the mean increments were not detected at 36 months after planting. The authors justify this fact by that the rapid growth of individuals in limestone and swage treatments that probably stimulated other forms of competition, such as competition for space, light, and water, which may have caused this stagnation even before the control treatment.

Maeda et al. (2015) also observed the yield solid volume of $E$. benthamii at 12 months with the application of $3 \mathrm{t} \mathrm{ha}^{-1}$ lime mud in an Ferralsol, with a dose similar to this study. However, with an increase of this dose to $6 \mathrm{t}$ $\mathrm{ha}^{-1}$ the planting did not show any increment in relation to the absence of the residue, and at 22 and 47 months, the lime mud did not increase solid timber volume. The authors inferred that lime mud has a faster effect on the reduction of $\mathrm{Al}$ saturation, showing no high residual effect for maintenance of low Al saturation, and this may be the factor that contributed to the lack of response over time.

In a study conducted by Rodrigues et al. (2016), the application of limestone promoted an increase in eucalyptus diameter, with greater increments in this dendrometric attribute than in vertical growth, similarly to the present study, which also showed greater increments in diameter than in height. In turn, Vieira \& Weber (2017)

FLORESTA, Curitiba, PR, v. 50, n. 4, p. 1788 - 1797, out/dez 2020

Pfleger, P. et.al.

ISSN eletrônico 1982-4688

DOI: 10.5380/rf.v50 i4. 65682 
obtained improvements in the soil chemical attributes after limestone application, which provided an increment in height, diameter, and biomass of E. camaldulensis seedlings.

Rodrigues et al. (2016) observed an increase in height, up to $1.50 \mathrm{~m}$, on E. urophylla $x$ E. grandis clonal plants cultivated in Cerrado, at 18 months after the addition of limestone, on the surface or incorporated. After the addition of limestone and gypsum, the increase was up to $2.10 \mathrm{~m}$. They also found $56 \%$ increments in stem with an application of $3.5 \mathrm{~kg} / \mathrm{ha}$ of limestone in the ridge band surface reaching $23.2 \mathrm{~m}^{3} \mathrm{ha}^{-1}$, and $99 \%$ with limestone application on the total area with gypsum added in the ridge band, with $29.6 \mathrm{~m}^{3} \mathrm{ha}^{-1}$ of yield. Simonete et al. (2013) evaluated the lime mud potential as a source of Ca for Eucalyptus saligna, and its effects on nutrient availability and dry mass production of aerial parts. They observed an increase in mass production after applying the residue, whose response was similar to the application of limestone. However, the significant response occurred only in plants cultivated in Arenosol, whose attributes were more restrictive to growth, when compared to Alisol or Cambisol, as in the current study, mainly because of low CEC and low availability of $\mathrm{Ca}$ and $\mathrm{Mg}$.

Evaluating the productivity of eucalyptus (E. grandis $\mathrm{x}$ E. urophylla) in Ferralsol under different types of management, soil tillage, and planting fertilization, including cellulosic residues and timber ashes, Paes et al. (2013) observed an increase in timber volume at 83 months after applying high doses of pulp residues and ashes, when compared to areas that did not receive these residues. Thus, monitoring throughout its development is necessary to better assess the effect of applying correctives and products containing $\mathrm{Ca}$ on its growth, and potential periods of need for fertilization, which may become evident during the growth of the plants.

\section{Nutritional status of the plants}

Considering the sufficiency range for the elements $\mathrm{N}, \mathrm{P}, \mathrm{K}, \mathrm{Ca}$, and $\mathrm{Mg}$ according to the CQFS-RS/SC (2016), in general, the treatments resulted in enough contents for the eucalyptus culture. However, this not occurred for $\mathrm{Ca}$ and $\mathrm{Mg}$, which showed means of 0.246 and $0.171 \%$, respectively, while according to the manual should present between 0.60 and $1.00 \%$, for $\mathrm{Ca}$, and 0.50 and $0.80 \%$, for $\mathrm{Mg}$.

Nevertheless, it should be considered the possible differences between adequate levels of nutrients for each eucalyptus species, as presented by Millner \& Kemp (2012). The authors conducted a study in New Zealand with different species of eucalyptus to determine nutrient content in leaf tissue in different species and sites, and found significant differences between species with values ranging from 1.14 to $1.92 \%$ of $\mathrm{N}, 0.124$ and $0.193 \%$ of $\mathrm{P}, 0.57$ and $0.89 \%$ of $\mathrm{K}, 0.41$ and $0.75 \%$ of $\mathrm{Ca}$, and 0.21 and $0.38 \%$ of Mg. Haag et al. (1976) working with leaf analyses with five species of eucalyptus found values ranging from 1.41 to $2.12 \%$ of $\mathrm{N}$, from 0.08 to $0.12 \%$ of $\mathrm{P}$, from 0.27 to $0.48 \%$ of $\mathrm{K}, 0.27$ to $0.50 \%$ of $\mathrm{Ca}$, and 0.11 to $0.17 \%$ of $\mathrm{Mg}$. Therefore, it could be considered the lower $\mathrm{Ca}$, and $\mathrm{Mg}$ leaf contents as a characteristic of the species studied.

At 12 months, Maeda et al. (2015) did not observe significant differences in leaf contents of $E$. benthamii after lime mud application, with averages of $2.54 \%$ of N, $0.126 \%$ of $\mathrm{P}, 0.548 \%$ of $\mathrm{K}, 0.803 \%$ of $\mathrm{Ca}$, and $0.172 \%$ of $\mathrm{Mg}$. To the authors, there was no interference in $\mathrm{Mg}$ absorption despite the increase in $\mathrm{Ca} / \mathrm{Mg}$ ratio due to the addition of lime mud.

Assessing the effects of dolomitic limestone and lime mud application in two distinct soils with $E$. saligna planting, Simonete et al. (2013) observed a reduction in the leaf contents of $\mathrm{N}, \mathrm{P}, \mathrm{K}$, and $\mathrm{Mg}$, and the maintenance of $\mathrm{Ca}$ and $\mathrm{S}$ contents with lime mud applied in Alisol. Similar results were obtained with limestone, that maintained $\mathrm{Mg}$ and $\mathrm{Ca}$ leaf contents. In Arenosol the most significant changes occurred in $\mathrm{Ca}$ leaf content which was higher in the lime mud treatment followed by limestone. However, in this soil the Mg leaf content was not affected by lime mud, but increased with limestone. The results regarding $\mathrm{Ca}$ were explained due to the initial available contents in the soil, where the Arenosol showed high Ca content and the Alisol low content.

Vargas \& Marques (2017), studying the nutrition of leguminous trees, observed no response in macronutrient leaf contents after limestone and gypsum application, except for $\mathrm{K}$ content with gypsum that was higher when compared to the control and limestone treatments, which was explained by the lower growth of the plants. According to these authors, the absence of response regarding Ca content may be related to the effect of the previous soil acidity correction that overcome Ca deficiency. Unlike this study, Vicente Ferraz et al. (2016) observed that the $\mathrm{N}$ and $\mathrm{P}$ leaf content increased significantly in sewage mud treatments than in control and limestone treatment, at 6 months after planting E. grandis in Ferralsol. The increase in $\mathrm{N}$ contents was related to photosynthetic and growth rates of individuals, mainly in the early stage of development. The increase in $\mathrm{P}$ after 36 months, even being highly adsorbed by $\mathrm{Fe}$ and $\mathrm{Al}$ oxides present in large proportion in weathered soils, was caused by the mineralization of organic $\mathrm{P}$ from soil organic matter favoring the absorption of $\mathrm{P}$ by the plants over time. In addition, until the 18th month, the leaf content of $\mathrm{K}$ in the control was higher than the treatment with limestone and sewage mud.

The results of nutrient contents of the present study may be related to the soil and management of the planting area. The soil has a clayey texture (38\%) and high organic matter content (4\%), which gives it a high buffer power, and there may be greater adsorption of the mineral elements, with slower release to the roots of the 
plants. In addition, after the harvest of the previous culture in the area, the accumulation of decomposing vegetable residues that remain in the local can promotes changes in soil reactions $(\mathrm{pH})$ and nutrients cycling, which may decrease the magnitude of the corrective effect. Also, it has to be considered the periodic application of NPK fertilizer throughout the area, which can prevent possible effects from the treatments to these elements.

\section{CONCLUSIONS}

- The application of $1.75 \mathrm{tha}^{-1}$ of limestone in Humic Cambisol, incorporated in the seedlings planting furrow, with or without $1.38 \mathrm{t} \mathrm{ha}^{-1}$ of gypsum, changed the $\mathrm{pH}$ and contents of exchangeable $\mathrm{Al}, \mathrm{Ca}$, and $\mathrm{Mg}$ of the soil in samples from the layers of 0 to $20 \mathrm{~cm}$ and 20 to $40 \mathrm{~cm}$ collected in the furrow line.

- Limestone or lime mud with doses up to $3.5 \mathrm{t} \mathrm{ha}^{-1}$, as well as the dose of $1.38 \mathrm{t} \mathrm{ha}^{-1}$ of gypsum applied to the soil surface in total area or in the ridge band, did not change the soil $\mathrm{pH}$ and content of exchangeable $\mathrm{Al}, \mathrm{Ca}$, and $\mathrm{Mg}$ in the 0 to $20 \mathrm{~cm}$ and 20 to $40 \mathrm{~cm}$ layers of a Humic Cambisol.

- The application of $1.75 \mathrm{t} \mathrm{ha}^{-1}$ of limestone located in the ridge band of the seedlings, showed better performances in height and stem diameter at breast height in the early stage of growth of Eucalyptus dunnii on assessments made at 12 months and 15 months of cultivation.

- Liming in Humic Cambisol with doses up to $3.5 \mathrm{t} \mathrm{ha}^{-1}$ applied in total area or located in the ridge band and at planting furrow of the seedlings, similarly to the lime mud, and $1.38 \mathrm{t} \mathrm{ha}^{-1}$ of gypsum, did not affect the height and stem diameter of the trees, neither the timber volume of Eucalyptus dunnii at 24 months after planting.

- Both limestone, lime mud, and gypsum, evaluated at 12 months after planting, did not affect the leaf nutrient contents in Eucalyptus dunnii.

\section{REFERENCES}

ALMEIDA, J. A.; ERNANI, P. R.; MAÇANEIRO, K. C. Recomendação alternativa de calcário para solos altamente tamponados do extremo Sul do Brasil. Ciência Rural, v.29, p.651-656, 1999.

ALVARES, C. A. et al. Köppen's climate classification map for Brazil. Meteorologische Zeitschrift, Stuttgart, v.22, n.6, p.711-728, 2014.

AZEVEDO, G. B. de. et al. Estimativas volumétricas em povoamentos de eucalipto sob regime de alto fuste e talhadia no sudoeste da Bahia. Pesquisa Florestal Brasileira, v. 31, n. 68, p. 309, 2011.

CASTRO FARIA, Á. B. de; ANGELO, A. C.; AUER, C. G. Disponibilidade de macronutrientes em Eucalyptus saligna cultivados com lodo de papel reciclado. Floresta, v. 45, n. 2, p. 261-272, 2015.

COMISSÃO DE QUÍMICA E FERTILIDADE DO SOLO - RS/SC. Manual de calagem e adubação para os Estados do Rio Grande do Sul e de Santa Catarina. 11.ed. Frederico Westphalen: Núcleo regional Sul Sociedade Brasileira de Ciência do Solo, 376p, 2016.

D'AVILA, F. S. et al. Efeito do potássio na fase de rustificação de mudas clonais de eucalipto. Revista Árvore, v. 35, n. 1, 2011.

GUIMARÃES, C.do C.; FLORIANO, E.P.; VIEIRA, F.C.B. Limitações químicas ao crescimento inicial de Eucalyptus saligna em solos arenosos do Pampa Gaúcho: estudo de caso. Ciência Rural, v. 45, n. 7, p. 1183$1190,2015$.

HAAG, H. P.; et al. Análise foliar em cinco espécies de Eucalipto. IPEF 13:99 - 116, 1976.

HOMEM, B. G. C.; NETO, O. B de A.; SANTIAGO, A. M. F; DE SOUZA, G. H. Dispersão da argila provocada pela fertirrigação com águas residuárias de criatórios de animais. Revista Brasileira de Agropecuária Sustentável, v. 2, n. 1, 2012.

LIMA, E. de S. et al. Variabilidade espacial das propriedades dendrométricas do eucalipto e atributos químicos de um Neossolo Quartzarênico. Revista de Agricultura Neotropical, v. 4, n. 1, p. 1-11, 2017.

MAEDA, S.; GOMES, J. B. V.; BOGNOLA, I.A. Crescimento de Eucalyptus benthamii submetido à aplicação de lama de cal e cinza de madeira. Embrapa Florestas - Comunicado Técnico, 2015.

MEDEIROS, J.C. et al. Resíduo alcalino da indústria de celulose na correção da acidez de um Cambissolo Húmico alumínico. Revista de Ciências Agroveterinárias, v. 12, n. 1, p. 78-87, 2013. 
MIGUEL, E. P. et al. Ajuste de modelo volumétrico e desenvolvimento de fator de forma para plantios de Eucalyptus grandis localizados no município de Rio Verde-GO. Enciclopédia Biosfera, Goiânia, v. 6, n. 11, p. 1$13,2010$.

MILLNER, J. P.; KEMP, P. D. Foliar nutrients in Eucalyptus species in New Zealand. New forests, v. 43, n. 2, p. 255-266, 2012.

MIRANDA, D. L. C. de; JUNIOR, V. B.; GOUVEIA, D. M. Fator de forma e equações de volume para estimativa volumétrica de árvores em plantio de Eucalyptus urograndis. Scientia Plena, v. 11, n. 3, 2015.

PAES, F. A. S. V. et al. Impacto do manejo dos resíduos da colheita, do preparo do solo e da adubação na produtividade de eucalipto. Revista Brasileira de Ciência do Solo, v. 37, n. 4, p. 1081-1090, 2013.

POTTER, R. O.; CARVALHO, A. P.; FLORES, C. A.; BOGNOLA, I. Solos do Estado de Santa Catarina. Rio de Janeiro. Embrapa Solos. Boletim de Pesquisa e Desenvolvimento, n. 46, 2004.

R Core Team. R: A language and environment for statistical computing. R Foundation for Statistical Computing, Vienna, Austria, 2016. URL https://www.R-project.org/.

ROCHA, J. B. O.; POZZA, A. A. A.; CARVALHO, J. G. et al. Efeito da calagem na nutrição mineral e no crescimento inicial do eucalipto a campo em Latossolo húmico da Zona da Mata (MG). Scientia Forestalis, v.36, p.255-263, 2008.

RODRIGUES, F. A. V. et al. Produtividade de eucalipto aos 18 meses de idade, na região do Cerrado, em resposta à aplicação de cálcio, via calcário e gesso agrícola. Scientia Florestais, Piracicaba, v. 44, n. 109, p. 67-74, 2016.

SIMONETE, M. A. et al. Fornecimento de cálcio para plantas de Eucalyptus saligna por meio de aplicação de resíduo industrial lama de cal. Revista Brasileira de Ciência do Solo, v. 37, n. 5, p. 1343-1351, 2013.

TEDESCO, M. J. et al. Análise de solo, plantas e outros materiais. 2.ed. Porto Alegre, Universidade Federal do Rio Grande do Sul, 174p, 1995.

VARGAS, G.; MARQUES, R. Crescimento e Nutrição de Angico e Canafístula sob Calagem e Gessagem. Floresta e Ambiente, v. 24, p. 1-10, 2017.

VICENTE FERRAZ, A. de; MOMENTEL, L. T.; POGGIANI, F. Soil fertility, growth and mineral nutrition in Eucalyptus grandis plantation fertilized with different kinds of sewage sludge. New forests, v. 47, n. 6, p. 861876,2016

VIEIRA, C. R.; WEBER, O. L dos S. Fertilização mineral e calagem no crescimento de mudas de Eucalyptus camaldulensis. Revista Ecologia e Nutrição Florestal-ENFLO, v. 5, n. 2, p. 45-52, 2017. 